\title{
Optimizing the Security of the Indonesian State through Strengthening International Cooperation between Indone- sia and Malaysia in the Land Border.
}

\author{
Edward Yohanes and Joko Setiyono \\ Faculty of Law, Diponegoro University, Semarang - Indonesia \\ *email: Yohanesedward21192@yahoo.com
}

\begin{tabular}{|c|}
\hline Published: 30/03/2020 \\
\hline How to cite (in APA style): \\
\hline $\begin{array}{l}\text { Yohanes, E., Setiyono, J. (2020). Optimizing the Security of the Indonesian State through Strengthening Internat } \\
\text { operation between Indonesia and Malaysia in the Land Border. Jurnal Hukum Prasada, 7(1), 1-7. do } \\
\text { doi.org/10.22225/jhp.7.1.1485.1-7 }\end{array}$ \\
\hline
\end{tabular}

\begin{abstract}
Indonesia is an island nation consisting of land and sea areas. The constitutional foundation of Indonesia has regulated that the Unitary State of the Republic of Indonesia is an archipelagic nation characterized by an archipelago with territories whose boundaries and rights are determined by law. This is as regulated in Article 25 (A) of the 1945 Constitution of the Republic of Indonesia. The purpose of this research is the application of international cooperation between Indonesia and Malaysia in the land border area and the driving and inhibiting factors for international cooperation between Indonesia and Malaysia in the land border area. . The approach method used in this study is the Legal Research approach method. Implementation of International Cooperation between Indonesia and Malaysia in the Border Area, The application of international cooperation between Indonesia and Malaysia proves that there is an international interaction as a country that is close together in terms of geographical location. Drivers of factors and obstacles to international cooperation between Indonesia and Malaysia in the border of land areas. The role of the central, provincial and district / city government in developing border areas needs to be done appropriately and emphasizes three main points, namely: Regulators, Executors and Government facilitators as regulators are obliged to encourage structuring the rules that exist in the development and utilization of border areas in the decision making effort. Conclusion The application of the agreement made between Indonesia and Malaysia is a strategic step for the two countries to mutually reinforce sovereignty in the country's security efforts
\end{abstract}

Keyword: Optimization of the security of the indonesian state; through strengthening international cooperation between indonesia and malaysia, in the land border region.

\section{INTRODUCTION}

Indonesia is an island nation consisting of land and sea areas. The constitutional foundation of Indonesia has regulated that the Unitary State of the Republic of Indonesia is an archipelagic nation characterized by an archipelago with territories whose boundaries and rights are determined by law. This is as regulated in Article 25 (A) of the 1945 Constitution of the Republic of Indonesia. There are 17,504 islands that fall into the territorial sovereignty of the Unitary Republic of Indonesia according to the Maritime Maritime Sovereignty Coordinating Ministry for Maritime Affairs, where 16,056 islands have been standardized at the United Nations until July 2017 (Sulistyo, 2012).

Indonesia has regulated a juridical basis regarding national borders in Law No. 43 of 2008 concerning State Territory which regulates the national boundaries. Article 5 explains that "the National Territory's borders on land, waters, seabed and the underlying land and the air space above it are determined on the basis of bilateral and / or trilateral agreements 
regarding land boundaries, sea boundaries, and air borders and based on statutory regulations and international law (Syahfitri, 2014). Indonesia and Malaysia is one example of a country that borders directly on land, namely on the island of Kalimantan, precisely in the province of West Kalimantan which borders Sarawak (Malaysia). This region has access to and out of goods, and strategic cross-country crossings, both through legal and illegal channels. With close and affordable access makes interaction between the two countries more intensive between Indonesian citizens and Malaysia.

Cooperation between Indonesia and Malaysia has existed for a long time, factors such as social, economic, and cultural conditions that are almost the background of the various collaborations between Indonesia and Malaysia. Example, in Sambas Regency has a lot of potential and natural resources that can be developed as tourist attractions that are no less good than other regions in West Kalimantan. Considering the location of the Sambas Regency region is very strategic directly adjacent to East Malaysia, it is expected that there will be opportunities for cooperation in the field of tourism with East Malaysia. Tourism efforts and programs have been carried out by the two countries through the collaboration of Sosek Malindo (Asmarani, Suni, \& Nugrahaningsih, 2013).

Collaborations undertaken by Indonesia with other countries both bilaterally, regionally and multilaterally are Indonesia's efforts in realizing world order by establishing good relations with countries in the world, one of which is also a country with land borders directly with Indonesia, namely Malaysia (R. Putra, 2013). The Indonesian government is currently seriously cooperating with Malaysia to determine the border point between the two countries. This is to accelerate the settlement of a number of border points, each claiming or commonly called the Outstanding Boundary Problems (OBP) between Indonesia and Malaysia, which have been running for 40 years.

The current of globalization that occurred also became one of the factors causing the border region to be faced with complex problems, ranging from assertion of unfinished borders even to the problem of welfare-trans-national crimes such as (illegal trade both basic needs, drugs, weapons, illegal logging, human trafficking and smuggling) and so on. This is what needs to be done by Indonesia and Malaysia in an effort to deal with the threat of state security in the border region through cooperation channels (W. Putra, 2009). Border cooperation was first carried out by the two countries between Indonesia and Malaysia since 1967. The situation began with the existence of the PGRS Movement (Serawak Rakyat Guerrilla Forces), PARAKU (North Kalimantan People's Forces) and the remnants of the G-30-S / PKI Rebellion which has a different ideological basis, namely communism, this ideology basis is a potential source for the emergence of social and political insecurity against state security threats.

Overcoming a number of PGRS, PARAKU movements and remnants of the G-30-S / PKI Rebellion Indonesia and Malaysia agreed to carry out coordinated operations to overcome a number of PGRS / Paraku movements and remnants of the G-30-S / PKI Rebellion moving along the West Kalimantan border to Sarawak which disturbs the security stability of the two countries. The agreement relating to state security (Security Arrangment) was first revised in 1972 and continued for the second revision in 1984. The results of the first revision in 1972 had an impact on the two countries agreeing to bind cooperation in a security agreement in the border region, the 1972 Security Arrangment which ratified in Kuala Lumpur on April 6, 1972 by the Minister of Defense and Security / Pegab General of the Armed Forces Pangabeyan on behalf of the Government of the Republic of Indonesia and the Minister of HAL Ikhwal in Malaysia Tun Tun. Ismail Al Haj Bin Datuk Haji Abdul Rahman on behalf of Malaysia (Pura, 2012).

Another collaboration between Indonesia and Malaysia in the first socio-economic field was sparked by Datu Musa Hitam, Deputy Prime Minister of Malaysia and chair of the Malaysian General Border Committee (GBC), which was delivered at the XC GBC session in Kuala Lumpur on November 14, 1983. Cooperation discussed in the Malindo Social Cooperation Cooperation in several fields, including: first, Socio-cultural Sector, consisting of Education, Health, Arts and Culture and Youth and Sports, second, conomic, trade and transportation sectors, consisting of Industry, Trade, Transportation, Labor, Natural Resources and the Environment, third, Field of Safety / Security and Border Management, 
consisting of: Land Border Posts (PLBD), Sea Border Posts (PLBL), fourth, Educational Cooperation on Prevention of Smuggling and Border Infrastructure. Border Committe since 1983 in several fields, one of them is security in the border of land area. Cooperation between Indonesia and Malaysia in the 1972 Security Arrangement not only concerns the field of defense but there is an expansion in the scope of the RI-Malaysia border after the second revision to cover various types of fields, namely ideology, politics, social, culture, and economy.

World countries focus their studies on economic growth "the dominant focus of current economic policies for restoring an acceptable rate of economic growth from the Great Recession is macroeconomic, specifically monetary and fiscal policies". But to achieve development in the economic field of each country also requires the existence of a security system, especially countries that have territorial boundaries directly with other countries. International cooperation developed by Malaysia and Indonesia arises because of the dependence on the two countries. The collaboration was realized in an effort to play a significant role in the application of international law. The subject of law in this case the two countries include the rights and obligations of each involved must exist Relationships are built in the form of agreements to confirm the commitment between the two parties, including when deciding to cooperate in a particular organization, association or regime.

The realization of the commitments that had been mutually agreed between Indonesia and Malaysia is a consequence that must always be built between the two countries. Behavior that must be carried out by participants to always be consistent in fulfilling all the agreements that have been made. Agreements and agreements made in the Security Arrangment and GBC will not mean if the commitment to comply with the regulations made does not exist, it will even cause new problems in the two countries. This can happen because compliance is an attachment that must be present to the parties to fulfill the obligations or commitments contained in the agreement. Therefore, state behavior in terms of acting is regulated through a set of binding rules. There needs to be awareness between the two countries that entered into an agreement so that rights and obligations always go hand in hand. A security expert, Barry Buzan divides the security sector into five fields; military, political, environmental, economic and social. Military approach means only one of them in the national security system. The role of the military is focused on the capabilities of defense institutions, threat assessment and others. Socio-cultural and religious relations are needed to understand the dynamics of threats and interactions of security factors.

Culture of violence often experiences latent typologies of conflict because it is deeply rooted, especially in demographically and ethnically divided societies. In addition, security cannot be understood in a narrow sense, only from the point of view of the State (state security), assuming that if the people are prosperous (a state of full stomach), security will be created. The actions of the security forces themselves are seen as threatening the security of individuals or citizens. Security is not seen in a community perspective. The community is less invited to be aware of when, how and what kind of security threat it is. Security problems arise after a case of apparatus violence (state violence) against the community.

\section{METHOD}

The approach method used in this research is the Legal Research approach method, the research is obtained from research libraries and legal documents, which means that the research is carried out by examining existing library data and references (Ali, 2009). Data for a study is material that is used to answer research problems. Therefore, the data in the research problem can be solved. In this study the type of data collected is secondary. Secondary data can be in the form of primary legal materials, secondary legal materials and tertiary legal materials obtained by studying and reviewing literature research.

\section{RESULT AND DISCUSSION}

\section{Application of International Cooperation between Indonesia and Malaysia at the}




\section{Border Territorial TerritoryResults should be clear and concise.}

The application of international cooperation between Indonesia and Malaysia proves that there is an international interaction as a neighboring country in terms of geographical location. Interaction that is established between the two countries is very necessary, especially for people who live in the border areas of the two countries in Kalimantan, moreover the area that connects the path between the two countries there is a land border that makes the interaction between the two countries more intense. Interactions that have been established can trigger various kinds of problems encountered.In the Discussion, it is the most important of your article. Make the discussion correspond with the finding but do not reiterate the discussion.

This international interaction is the implication of globalization which has led to the emergence of various problems in world countries. Globalization is changing the overall environment in which countries operate, including how they formulate their security policies. Increasingly complex issues make the two countries form a cross-sectoral coordination and policy forum by involving several elements called the GBC. The GBC cooperation between the two countries was formed based on international treaties which in this case regulate border areas (security arrangements 1972 and 1984).

Along with the development of the Indonesia-Malaysia border region in 1984, the two countries signed a new agreement in the form of an agreement on the Border Crossing between the Republic of Indonesia and Malaysia, also known as the Border Crossing Agreement (BCA). With the entry into force of this agreement at once revoked the BCA in 1967. Over time the BCA agreement was re-agreed in 2006, but it has not yet been ratified.

Thus the cross-border agreement that is in effect today in 1984. The contents of the agreement regulate cross-border activities that can be carried out by Indonesian and Malaysian border communities, including family visits, social / entertainment activities, religious needs, business / trade, duties government and other needs agreed by the parties.

The existence of agreements and conventions between the agreed countries is expected to be able to harmonize the law between the two countries. Uniform law is directed primarily to avoid situations of legal conflict. The aim of the unificationist is to convince enough individual jurisdictions that the proposed uniformity in certain areas of law is a good thing and that they must change their laws to achieve that goal (Ahmad, 2013).

Cross-border implementation carried out by the two countries has a positive impact on the condition of social security in the border region, for example Sebatik Island. The implementation of cross-border policy implementation can be seen in six (6) indicators of social resilience capital, namely natural, physical, human resources, economic, financial, social, and political. First in terms of abundant natural resources, both in the form of agricultural and plantation products, such as oil palm, cocoa, and bananas, as well as the results of fish catches.

International cooperation is a relationship between two or more countries that have goals that can benefit each country. International Cooperation between one country and another in the form of bilateral, regional and multilateral cooperation. International Cooperation as a result of interdependence between one country and countries that have cooperation in certain fields.

According to Article 1 of the Charter of the United Nations which states that international cooperation is a result of interdependence and with respect for justice and international obligations.

Respect for justice and international obligations is sought primarily for:

a. Maintaining International Peace and Security.

b. Developing friendly relations between nations based on the principle of equal rights; and

c. Achieve international cooperation in solving international problems in the economic, social, cultural or humanitarian fields. 
Cooperation between Indonesia and Malaysia is a form of bilateral cooperation between the two countries. International cooperation undertaken by Indonesia with Malaysia regarding land borders in Kalimantan is a form of interaction between Indonesia and other countries as a manifestation in the politics of the Indonesian State as contained in the fourth paragraph of the 1945 Constitution of the Republic of Indonesia which is commonly referred to as the goal of the Indonesian State. One of the objectives of the State of Indonesia stated that the Indonesian nation participated in carrying out world order (Puspita, 2013).

In order to achieve world order, the State of Indonesia entered into several collaborations to prevent disputes, especially with neighboring countries bordering the land area, namely Malaysia, on the Borneo mainland.

The closeness of the land border between Indonesia and Malaysia has led to intense interaction between the two countries. The increasingly intense interaction between the people of the two countries, both directly and indirectly, triggered the various problems encountered. Thus encouraging the formation of a cross-sectoral coordination and policy forum that carries out technical functions involving various elements called the GBC (General Border Committee). This GBC is one of the international regimes formed based on the agreement of the two countries.

Second, in terms of physical capital, it helps the community in terms of cross-border Pos service facilities in Sei Pancang to be able to cross to Tawau with easy access. Third, related to human resources in terms of health which began to increase with the availability of adequate health services. The fourth is related to economic and financial capital which is given easy access to sell agricultural and marine products to the territory of Malaysia. The fifth in terms of social capital facilitates interaction between families in other countries.

Next table. Border Crossers by using Cross Border Pass through Sei Piling Post 2010 -2014. The existence of cross-border countries also provides restrictions in free trade activities, especially in the ASEAN region to be controlled. Because ASEAN is committed to developing its integrated regional market, ASEAN needs a regulatory regime that can facilitate the free movement of intra-ASEAN trade and investment.

Table 1

Border Crossers by using Cross Border Pass through Sei Piling Post 2010-2014

\begin{tabular}{lcccc}
\hline \multirow{2}{*}{ Years } & \multicolumn{2}{c}{ Indonesian } & \multicolumn{2}{c}{ Foreigners } \\
\cline { 2 - 5 } 2010 & In & Out & In & Out \\
2011 & 28479 & 27895 & 92 & 97 \\
2012 & 29107 & 29107 & 109 & 1 \\
2013 & 32251 & 32251 & 106 & 110 \\
2014 & 5358 & 5358 & 0 & 0 \\
2013 & 4948 & 4948 & 0 & 0 \\
2014 & 5358 & 5358 & 0 & 0 \\
\hline
\end{tabular}

The application of a cross-border agreement needs to be legalized between the parties. Legalization of a cooperation agreement is important, because the higher the level of legalization of an agreement will encourage the country to comply with the agreement that has been made and vice versa if the legality is low, then the state has the right not to comply with the agreed agreement.

The application of this agreement is expected to be well systemized. Due to its very nature, the 'system' can be expected to be relatively isolated in the sense that there is no 'extra-system' actors affecting the 'intra-system' relationships. So that it can run well between the two countries, namely Indonesia and Malaysia.

The concept of the State Security Law does not only cover military security but also human security. Human security is the choice because this concept comprehensively is able to bridge the interests of security between the interests of military security with economic, food, energy, personal, political, community, and environmental security.

Norway, Canada and Japan, Norway, are among the countries that have implemented human security in their security policies. And the three countries proved to 
have relatively solid national security and very high Human Development Index (HDI) scores, respectively in the order of 2, 4, and 8 in 2007.

State security is the goal of every country in the world as in European countries applying that state security is a goal for the future of the brand country so that its security system is stable. Indeed, the government was reluctant and wanted to stop progress towards an EU security and defense policy. In order to achieve world order, the State of Indonesia entered into several collaborations to prevent disputes, especially with neighboring countries bordering the land area, namely Malaysia, on the Borneo mainland.

The closeness of the land border between Indonesia and Malaysia has led to intense interaction between the two countries. The increasingly intense interaction between the people of the two countries, both directly and indirectly, triggered the various problems encountered. Thus encouraging the formation of a cross-sectoral coordination and policy forum that carries out technical functions involving various elements called the GBC (General Border Committee). This GBC is one of the international regimes formed based on the agreement of the two countries (Yeni, 2014).

Understanding borders in general is a demarcation line between two sovereign states. At first the border of a State or States border was formed with the birth of a State. Previously people living in certain areas did not feel the difference, in fact they were often from the same ethnic group. However, with the emergence of the State, they were separated and with the demands of the State they had different nationalities.

\section{Driving and inhibiting factors of Indonesia-Malaysia International Cooperation in the Land Border Area}

A country has a different diversity when viewed from natural resources, climate, and social culture. This is what requires the state to play an active role in efforts to encourage the availability of needs to meet the needs of citizens. Indonesia and Malaysia, for example, are seen from natural resources.

Indonesia has natural and non-biological natural resources over Malaysia. The total area of Indonesia is $1,904,569 \mathrm{~km} 2$ which consists of $4.8 \%$ of the sea and the rest is land. While the total area of the State of Malaysia is $329,847 \mathrm{~km} 2$ which only has $0.3 \%$ of the sea. This explains that Indonesia is bigger than Malaysia in terms of geographical factors. Different natural conditions encourage the two countries to collaborate in various fields.

In handling the management of Indonesia's border region with the state of Malaysia, the government still prioritizes land boundaries, because the clarity of physical boundaries on land greatly influences the implementation of development. From the state borders on land it can be seen that Indonesia borders land with Papua New Guinea, Malaysia and the Democratic Republic of Timor Leste / East Timor.

The role of the central, provincial and district / city government in the development of border areas needs to be done appropriately and emphasizes on three main things, namely: Regulators, Executors and facilitators The government as regulator is obliged to encourage the arrangement of the existing rules in the development and utilization of border areas in decision making effort.

Basically, managing border areas also involves managing natural resources. Reallocating resources globally is a natural progression in the development of enterprises in response to economic globalization. This is the impact of globalization that drives every country through its investors in the company managing natural resources.

So that regulations are needed in regulating this management, especially in the border areas of the country. The function of this regulation must be carried out transparently, democratically and fairly. As executor, the government implements as a policy program that directly touches all levels of society. As a facilitator, the government encourages the creation of a conducive climate for the development and utilization of small island areas through the provision of various forms of supporting infrastructure in the area in question. From the juridical aspect, the handling of land border areas still requires an adequate set of laws and regulations to maintain and empower them. 
Reviewing various laws and regulations such as Laws, Government Regulations, Presidential Decrees etc. relating to the handling of national borders and borders both on land and sea boundaries is likely to be very urgent. PP No. 38 of 2002 concerning the Geographical Coordinate List of Indonesian Archipelagic Lines, needs to be immediately revised following the decision on ownership of the islands of Sipadan and Ligitan. The existence of security in national borders is an effort to prevent acts of terrorism in world countries. Terrorism has subsided and hence these programs are not needed (Surya, 2014).

Cultural aspects of the community at the border also become a problem in itself. "To identify distinctive ASEAN cultures of conflict and cooperation". Traditional fishing activities or other activities around the area can also be a trigger for border conflict. For example: between Indonesia and Papua New Guinea, even though they have an agreement on land and water boundaries, it can also be a crucial issue. There are several economic and cultural aspects that have the potential to become conflicts, where cultural similarities, economic interests and familial ties between villages that exist on both sides of the border, cause claims to traditional rights have developed into a complex. The Warasmol case and the use of Fly River for shipping traffic and natural resources by residents of the two countries living on both sides of the river, not infrequently cause problems that have implications for border disputes.

\section{CONCLUSION}

From the discussion explained above, it can be concluded that the application of the agreement made between Indonesia and Malaysia is a strategic step for the two countries to strengthen mutual sovereignty in the country's security efforts. The agreements that have been made ranging from Security Arrangement, GBC to BCA which are rooted in crossborder issues. The implementation of the agreement from the cooperation will not run optimally if the compliance to carry out the rights and obligations is not carried out properly.

The main factor in encouraging the international cooperation between Indonesia and Malaysia is the similarity of ideological culture, and its natural resources. This can be realized when between countries work together to have the same vision and goals for the welfare of the people.

\section{REFERENCES}

Ahmad, N. (2013). Fill out the Indonesian Agreement with Malaysia. Jakarta: Sinar Grafika.

Ali, Z. (2009). Legal Research Methods. Jakarta: Sinar Grafika.

Asmarani, M., Suni, B., \& Nugrahaningsih, N. (2013). Kerjasama Sosial dan Ekonomi MalaysiaIndonesia (Sosekmalindo) (Studi Kasus Pengembangan Kawasan Pariwisata di Kabupaten Sambas). Jurnal Program Magister IImu Sosial Universitas Tanjungpura, 1-16. Retrieved from https://media.neliti.com/media/publications/9533-ID-kerjasama-sosial-dan-ekonomi-malaysiaindonesia-sosekmalindo-studi-kasus-pengemb.pdf

Pura, I. (2012). Ideology Basics. Bandung: Citra Aditya Bakti.

Puspita, T. (2013). Definition of Cooperation between Indonesia and Malaysia. Jakarta: Balai Pustaka.

Putra, R. (2013). Indonesian Cooperation with Malaysia. Jakarta: Balai Pustaka.

Putra, W. (2009). Completion of the Indonesia-Malaysia Border. Bandung: Citra Aditya Bakti.

Sulistyo, H. (2012). Understanding Indonesia in Broad Meaning. Bandung: Citra Aditya Bakti.

Surya, A. (2014). Handling Cooperation between Indonesia and Malaysia. Bandung: Citra Aditya Bakti.

Syahfitri, L. (2014). Analisis Derajat Kepatuhan Kerjasama General Border Committee Malaysia â€ Indonesia (Studi Kasus: Perbatasan Darat Di Kalimantan). Yogyakarta: Post-Graduate International Relations Faculty of Social and Political Sciences, Gadjah Mada University. Retrieved from http://etd.repository.ugm.ac.id/penelitian/detail/75239

Yeni, A. (2014). Problems of Cooperation between Indonesia and Malaysia. Jakarta: Balai Pustaka. 